\title{
ATTRACTIVENESS OF THE LUZNAVA MANOR'S OFFER
}

\author{
Lienīte Litavniece \\ Iveta Dembovska \\ Inese Silicka \\ Rezekne Academy of Technologies, Latvia
}

\begin{abstract}
The Luznava Manor is one of the newest tourist attractions in Rezekne municipality, which is still in development. The paper is the result of the Rezekne Academy of Technologies (RTA) research grant "Feasibility study of tourism product development for the Luznava Manor". The paper is aimed to assess the attractiveness of the Luznava Manor. The theoretical aspects of destination attractiveness and criteria for its assessment are reviewed in the paper. During the research study, the expert questionnaire was developed and practically approbated; the results of the expert survey are summarized in the paper. The attractiveness of the Luznava Manor's offer is assessed in accordance with the following criteria: ease of access, exterior, visitors' facilities, restrooms, staff, accessibility, nature factors, importance of culture, and services. Currently, it is relatively difficult to evaluate the Luznava Manor's tourism product as a global or European level tourist destination. According to the authors, the Luznava Manor is rather to be considered as a tourist destination of national, regional and local significance.
\end{abstract}

Keywords: Luznava Manor, supply attractiveness, destination attractiveness.

\section{Introduction}

Tourism is considered to be attractive not only by the population using various services offered by the industry such as accommodation, catering, transportation, etc., but also by the public administration establishments of various levels seeing tourism as a source of additional revenues.

In the planning period 2014-2020, tourism is not included in the policy regulations of the European structural and investment funds as a thematic aim, since it is viewed as a mean or an industry, not as an aim itself. Though, there are many opportunities of purposeful investments in the tourism industry provided in the regulations (Regional Policy, 2014).

In Latvia, both the legislative base and planning documents available at the national and municipal level regulate tourism sector development, thus proving significance of the industry for the national economy. 
Attention to the tourism sector is drawn to by the planning and regulatory documents, and by the researchers providing theoretical solutions for the sector's evaluation and development.

The rapid development of the tourism industry enhances competition among regions, countries, cities, and particular tourism objects. Consumers become more selective, and a tourism object must be competitive in order to ensure a continuous and increasing flow of tourists.

As a result, an increasing attention is paid to the field of destination attractiveness in tourism. There are many researchers who have studied theoretical aspects of the concept: C.A.Gunn (Gunn, 1979, 1988), A.A.Lew (Lew, 1987), Y.Hu, B.J.Ritchie (Hu, Ritchie, 1993), T.Mihalič (Mihalič, 2000), S.Formica (Formica, 2000), E.Kušen (Kušen, 2002), S.Vengesayi (Vengesayi, 2003), B.Pikkemaat (Pikkemaat, 2004); B.J.Ritchie, G.I.Crouch (Rithie, Crouch, 2005), S.S.Kim, J.Agrusa (Kim, Agrusa, 2005), Y.Yoon, M.Uysal (Yoon, Uysal, 2005), S.Um, K.Chon, Y.Ro (Um, Chon, Ro, 2006), D.Krešić (Krešić, 2007), G.Omerzel, T.Mihalič (Omerzel, Mihalič, 2008), M.F.Cracolici, P.Nijkamp, (Cracolici, Nijkamp, 2009), D. Krešić, D.Prebežac (Krešić, Prebežac, 2011).

The Luznava Manor is a relatively new tourist destination in Rezekne municipality; it was opened just at the beginning of 2015 after the renovation. One of the main objectives is to ensure the attractiveness of the manor as a tourist destination.

The aim of the research is to evaluate the attractiveness of the Luznava Manor's tourism offer.

To achieve the aim, the following tasks are implemented:

- theoretical literature about the term "destination attractiveness" and about its evaluation criteria was explored;

- $\quad$ research methodology was described;

- $\quad$ attractiveness of the Luznava Manor's tourism offer was evaluated;

- proposals to enhance the attractiveness of the Luznava Manor's tourism offer were developed.

Research methods applied: monographic, expert survey, logical construction, scientific induction and deduction.

\section{Theoretical aspects of destination attractiveness}

Since the second half of the last century, many researchers in the tourism industry-related studies have began to use the term "destination attractiveness", by the "destination" meaning not only territory (e.g., a region, a country, a city, etc.), but also specific sites (for instance, a castle, a public park, a restaurant, etc.). The exploration of the available explanations of the term "destination attractiveness" leads to the conclusion that, in any of them, a particular 
dimension is accentuated, though conceptually each definition emphasizes that it is a decision-making process (see Table 1).

Table 1 Definitions of the term "destination attractiveness"

(prepared by authors)

\begin{tabular}{|l|l|l|}
\hline \multicolumn{1}{|c|}{ Author } & \multicolumn{1}{|c|}{ Definition } & \multicolumn{1}{c|}{ Keywords } \\
\hline Mayo \& Jarvis (1981) & $\begin{array}{l}\text { A combination of the relative } \\
\text { importance of individual benefits and } \\
\text { the perceived ability of the destination } \\
\text { to deliver individual benefit }\end{array}$ & Perceived ability \\
\hline $\begin{array}{l}\text { Hu, Y. \& Ritchie, B.J.R. } \\
(1993)\end{array}$ & $\begin{array}{l}\text { The feelings, beliefs, and opinions that } \\
\text { an individual has about a destination's } \\
\text { perceived ability to provide satisfaction } \\
\text { in relation to his or her special vacation } \\
\text { needs }\end{array}$ & Perceived ability \\
\hline $\begin{array}{l}\text { Lue, Crompton, and } \\
\text { Stewart (1996, p. 43) }\end{array}$ & $\begin{array}{l}\text { Something recognised by individuals as } \\
\text { a factor that influences their decision- } \\
\text { making of pleasure travel. }\end{array}$ & $\begin{array}{l}\text { A factor that } \\
\text { influences decision- } \\
\text { making }\end{array}$ \\
\hline Pompurova (2009) & $\begin{array}{l}\text { A comprehensive statement } \\
\text { attractiveness territory in relation to } \\
\text { decision - making in tourism visitors } \\
\text { about the destination of their travel and } \\
\text { stay }\end{array}$ & $\begin{array}{l}\text { Comprehensive } \\
\text { statement }\end{array}$ \\
\hline Leask (2010) & $\begin{array}{l}\text { Tourism attractions play a crucial role } \\
\text { in the success of a tourism destination, } \\
\text { where they act as key motivators for } \\
\text { visits and as resources for local } \\
\text { communities. }\end{array}$ & $\begin{array}{l}\text { Key motivators for } \\
\text { visit }\end{array}$ \\
\hline
\end{tabular}

There are different opinions among the scientists on what is more important when assessing the attractiveness - supply or demand:

1. Consider attractiveness from a supply perspective (Romsa, 1981).

2. Consider attractiveness from a demand perspective (Muller, 1991, Vengesayi, 2003; Tasci, 2007).

3. Attractiveness of a tourist destination can be divided into two main groups, namely the supply- and demand- oriented (Ferrario, 1979; Piperoglou, 1966; Kšir, 2012; Schejbal, 2013, Gunn, 1979).

American scholar C.A. Gunn has developed a theoretical model of destination attractiveness (Figure 1), where attractiveness evaluation is viewed as a complex measure involving subjective and objective criteria, which are assessed in the context of supply and demand. 


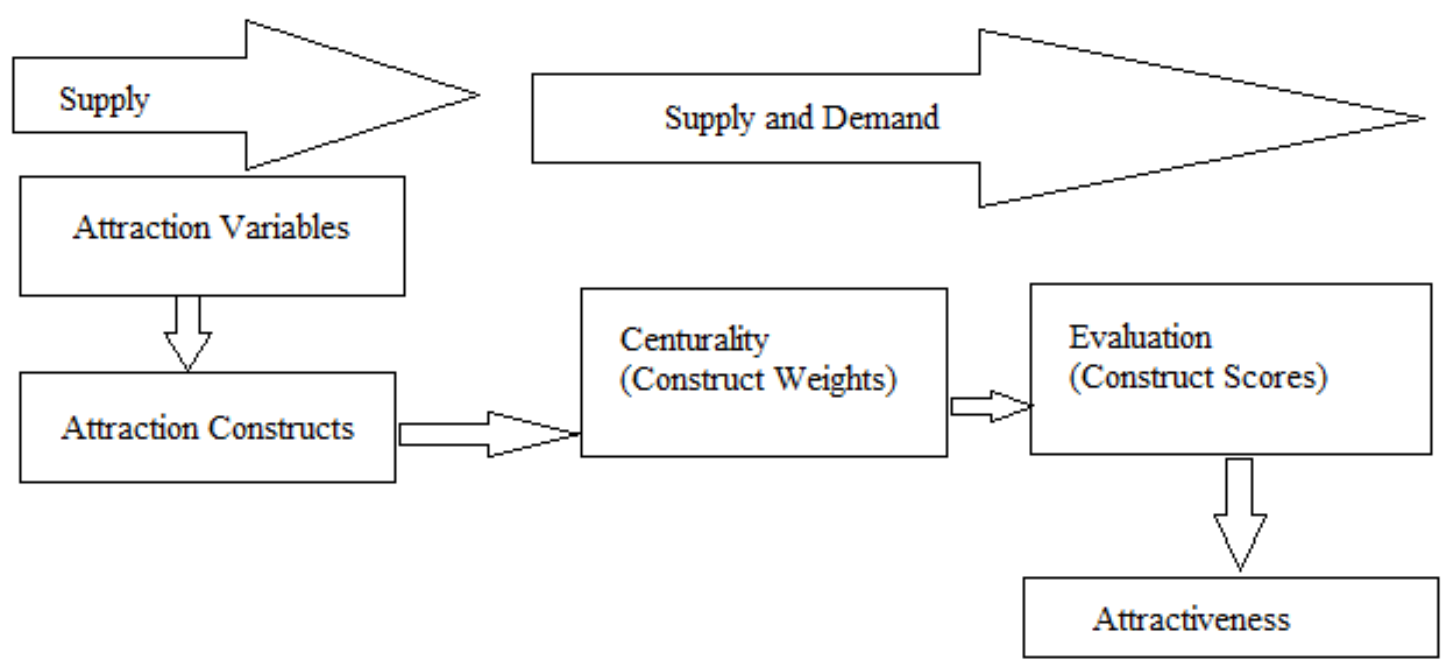

Figure 1 Theoretical model of destination attractiveness (Gunn, 1979)

Assuming this model as the base for destination attractiveness evaluation, the need occurs to establish criteria that could be used to understand the level of destination attractiveness. It should be noted that there are a variety of evaluation criteria available in the theoretical literature (Figure 2).

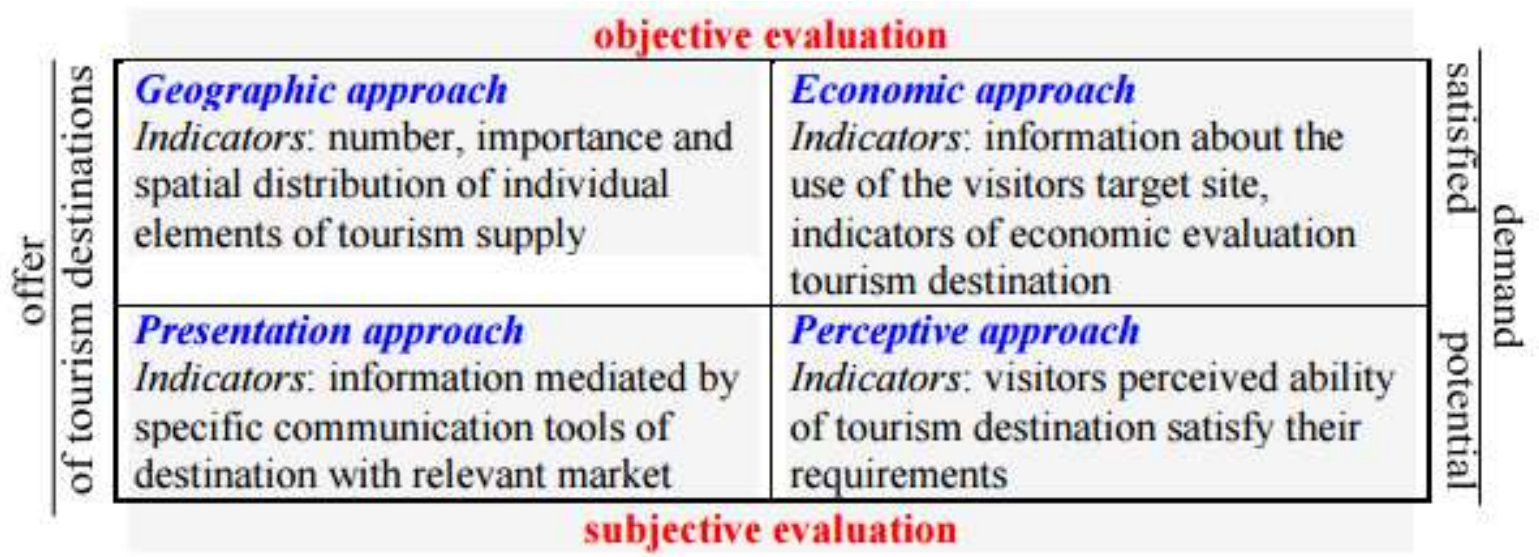

Figure 2 Basic approaches to assessing the attractiveness of a tourism destination

(Pompurová, 2009)

The authors of this research have evaluated destination attractiveness only from the point of view of supply, therefore only the criteria characterizing the tourism offer are analysed.

Based on the approach for the destination attractiveness evaluation illustrated in Figure 2, it has to be concluded that both objective (geographic approach) and subjective (presentation approach) criteria can be used in the context of the offer.

The geographic approach is based on the characteristics of the site or object in accordance with tourism geography criteria - terrain, climate, landscape, 
water, flora, fauna, architectural and cultural heritage, and historical facts. C. Schejbal argue that, of all the above mentioned, the most important item that characterizes this approach is the landscape and the climate (Schejbal, 2013).

The presentation approach, in fact, can be considered as a marketing communication that is characterised by all the available information about the destination (Formica, 2000; Pompurova, 2010).

A. Meinung, however, proposes to divide all criteria in three large groups and to describe each of them using a particular indicator: primary or static factors (landscape, climate, means of travel), secondary or dynamic factors (tourism supply, administrative and political settings, trends in tourism), tertiary or current factors (marketing-oriented activities or operations, organisation) (Meinung, 1989).

C. Morachat defines 8 attributes that can be used to describe destination attractiveness. Those are natural factors, cultural factors, recreational and shopping facilities, infrastructure, accessibility, reception, services, cost/price (Morachat, 2003).

Overall, there are many models that could be used to evaluate destination attractiveness.

Many researchers have developed and offer their own criteria to measure destination attractiveness. In this research, the attractiveness of the Luznava Manor's offer is assessed in accordance with the following criteria: ease of access, exterior, visitors' facilities, restrooms, staff, accessibility, nature factors, importance of culture, and services.

\section{Attractiveness evaluation of the Luznava Manor's offer}

Based on the destination attractiveness criteria described in the theoretical literature, the authors have developed the expert questionnaire. Four experts were selected: all of them worked in the tourism sector in the region and were aware of the Luznava Manor as a tourism product, had knowledge of its offer, as well they were specialists in the field of tourism - they have knowledge, necessary skills and competencies to be as expert. Also they have theoretical and practical experience in tourism field.

The expert questionnaire consisted of 3 sections: in the first, control questions were included, in the second, questions about the Luznava Manor's competitiveness were provided, and, in the third section, the experts were requested to assess the Luznava Manor's services. The average values for each question were calculated. The experts had to rate each criterion on a 5 point scale.

Tourism product attractiveness directly connected with tourism product competitiveness. So, according it. 
Table 2 Assessment of the Luznava Manor as a tourism product (prepared by authors)

\begin{tabular}{|c|c|c|}
\hline Criteria & Characteristic & $\begin{array}{l}\text { Average } \\
\text { expert } \\
\text { ratings }\end{array}$ \\
\hline $\begin{array}{l}\text { Compliance with the } \\
\text { sustainable tourism } \\
\text { principles and criteria }\end{array}$ & $\begin{array}{l}\text { The Luznava Manor as a tourist product is developed } \\
\text { preserving local resources and ensuring sustainable } \\
\text { development. The product is developed taking into } \\
\text { account the local cultural, natural, social, and economic } \\
\text { factors. When creating the site, cooperation with } \\
\text { companies in the surrounding area was established }\end{array}$ & 5.00 \\
\hline $\begin{array}{l}\text { Compliance with the } \\
\text { basic principles of } \\
\text { innovative tourism } \\
\text { product }\end{array}$ & $\begin{array}{l}\text { In comparison with the offers already existing on the } \\
\text { market, a new service, a new type of existing service, } \\
\text { effective technological process, production technique, a } \\
\text { new or improved product presentation, etc., are offered } \\
\text { helping a company to maintain and strengthen its } \\
\text { market position, providing increased competitiveness, } \\
\text { increased turnover, and other advantages. }\end{array}$ & 5.00 \\
\hline Export capacity & $\begin{array}{l}\text { The Luznava manor as a tourist product is suitable for } \\
\text { the needs of foreign tourists; the probable barriers such } \\
\text { as a language barrier and a barrier of access to } \\
\text { information (information about the product is available } \\
\text { in several languages, in a variety of information } \\
\text { channels, including the Internet (own website, social } \\
\text { networks, etc.)) are absent; the product is suitable for } \\
\text { needs of the target market. The Luznava Manor as a } \\
\text { tourism product complies with target markets and target } \\
\text { audiences defined in Latvia's Tourism Development } \\
\text { Guidelines for 2014- } 2020 \text { and Latvia's Tourism } \\
\text { Marketing Strategy for } 2010 \text {-2015. }\end{array}$ & 3.75 \\
\hline Quality & $\begin{array}{l}\text { The Luznava manor as a tourist product is designed } \\
\text { according to the needs of consumers; the company } \\
\text { controls and monitors the quality of service provided at } \\
\text { all stages of its delivery. }\end{array}$ & 4.50 \\
\hline $\begin{array}{l}\text { Compliance with the } \\
\text { high added value } \\
\text { tourism product }\end{array}$ & $\begin{array}{l}\text { The value, which the company has added to the } \\
\text { resources while providing services by using human } \\
\text { knowledge and professionalism, efficient use of } \\
\text { resources and their potential. }\end{array}$ & 5.00 \\
\hline $\begin{array}{l}\text { Compliance with the } \\
\text { characteristics of } \\
\text { tourism product with } \\
\text { high engagement of } \\
\text { tourists and acquiring } \\
\text { experience }\end{array}$ & $\begin{array}{l}\text { Customers have the opportunity to participate, engage, } \\
\text { and experience the emotions, gaining new experiences } \\
\text { and spending high-quality leisure time. }\end{array}$ & 4.50 \\
\hline
\end{tabular}


The obtained expert evaluation provides information on the attractiveness of the Luznava Manor as a tourism product, assessing it from the point of view of sustainability, export capacity, added value, gaining experience, innovation, and quality. The highest assessment by the experts was given to added value, sustainability, and innovation. That means that the Luznava manor as a tourist product has overall significant potential for development. The lowest assessment was given to export capacity. All tourist attractions/ destinations can be divided into several levels:

- global level tourism destinations and objects;

- European level tourism destinations and objects;

- national level tourism destinations and objects;

- regional level tourism objects;

- local level tourism objects.

That means it is necessary to determine a destination level of the Luznava Manor as a tourist object and then to build an appropriate supply. The authors believe that the current Luznava Manor's offer is focused on local tourists.

Next, the experts evaluated the Luznava Manor's services in accordance with the following criteria: ease of reach; exterior; visitors' facilities; restrooms; staff; accessibility; nature factors; services; importance of culture.

Each of these criteria was provided with a set of indicators. In Figure 3, average values of each criterion are summarized.

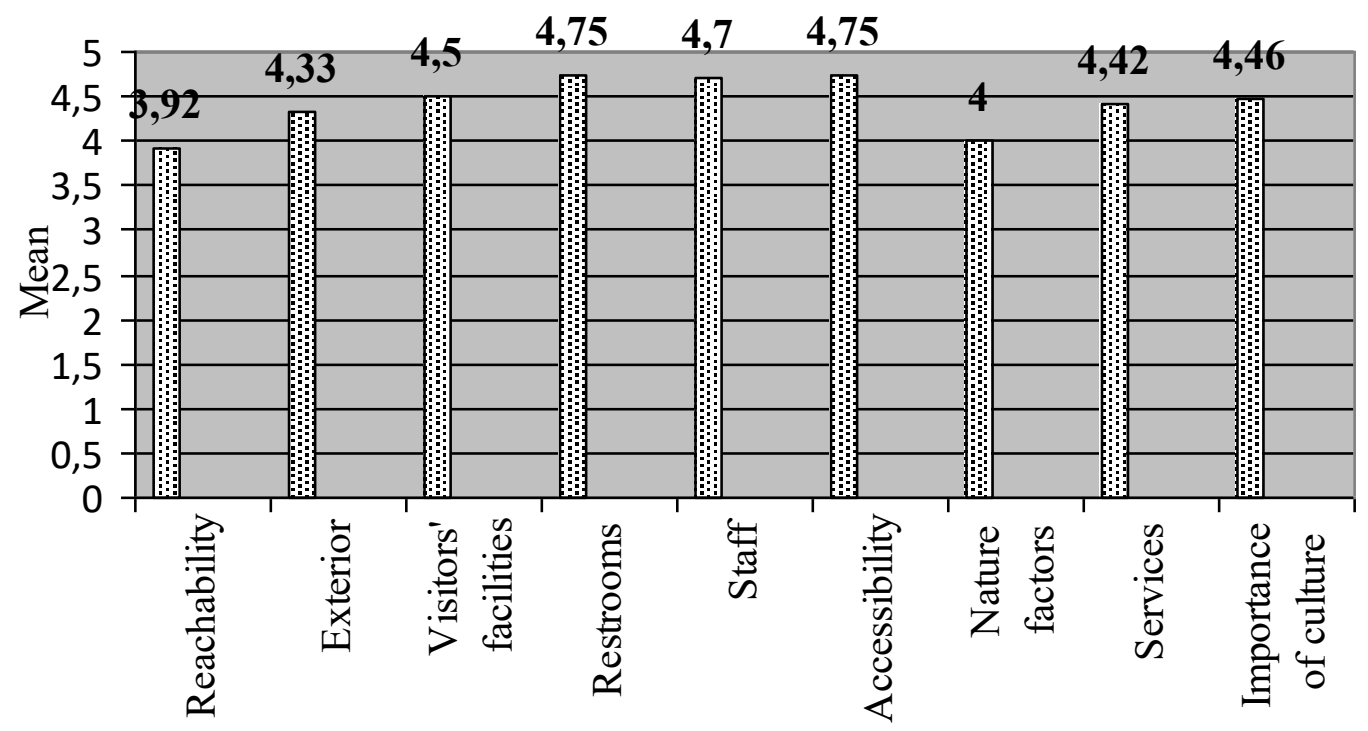

Figure 3 Average values of the Luznava Manor's services assessed by the experts (authors' calculations) 
The obtained results make it possible to assess the attractiveness of the Luznava Manor's services and at the same time to identify the critical points which have to be addressed closer in order to improve and develop the attractiveness of the services.

The criterion "ease of reach" has the lowest average value. The Luznava manor as a tourist attraction is situated in Rezekne municipality and, in this case, the criterion "ease of reach" is defined by the authors as tye lack of an element "direction signs in the parish area", for example, on the road A13 RezekneDaugavpils, and direct object reach in Luznava parish. The experts' assessments of that criterion are not of maximum value. The lowest score (3.5) has an element "parking facilities" because the existing parking space is insufficient.

The criterion "exterior" is characterised by nine elements. In the experts' opinion, the Luznava Manor has to focus significantly on the development of recreation zones in the park. The Luznava Manor Park is adjacent to the Luznava Manor, and it could become a major tourist attraction. Given that the Luznava Manor's renovation was completed relatively recently, the criteria assessing the external appearance by the elements "first impression" and "technical condition of building" have received the highest score. In the experts' opinion, there is a lack of references to special offers in the manor.

Summarizing the opinions of the experts regarding the criterion "visitors facilities", the experts point to the availability of the Internet and its quality as insufficient (e.g. connection speed); if one takes into account that nowadays it is an important competitive factor, it needs to be improved.

The staff affects competitiveness of any tourism company (e.g., by its competence, knowledge, kindness, attention, etc.). The experts point out that creating the manor's customer service standards, a special attention should be paid to the employees" "first and the last contact" with the client.

A customer's decision-making is affected by both tangible, and intangible elements of the service, though the intangible services are those leaving a longterm exposure to the client's behaviour, because they help the customer to decide upon its quality and purchasing.

Evaluating a criterion "the staff", particularly an element "appearance of the employees", the experts haven't provided the highest score to it either; it evidences that it is necessary to focus more on the Luznava Manor's image development, including the employees' appearance (clothing and shoes, hair style, etc.) and also professionalism, language skills.

The criterion "accessibility" is characterized by prices, as both the theoretical literature and the practice prove that price is a major attraction instrument. The experts evaluate the price as overall satisfactory. The authors believe that the assessment corresponds to the existing offer and the target group of services. 
The Luznava Manor area includes a landscape park (23.7 ha) with a system of seven water ponds (2.6 hectares). Taking into account the experts' assessment, it can be concluded that the Luznava Manor provides both natural landscape attractiveness (scenic attractiveness of wild nature), and access to the existing water bodies in the park. Though, to make them attractive for tourists, in the authors' opinion, it is necessary to adjust these landscapes with the needs of the tourists, for example, designing open-air recreational zones in the park, etc.

The experts believe that the Luznava Manor's services should be linked to other tourist products in Rezekne municipality to create complementarity of the services. The Manor should develop a single united product along with the other tourism service providers, because as a separate destination the Manor can serve only in specific cases (concerts, entertainment events, etc.) for local tourists. In order to increase attendance and the export capacity, the Manor's offer should be included in the general tourist routes in cooperation with travel agencies, route developers. The Manor can be an attraction for tourists staying in nearby towns or the neighbourhood.

The experts consider that it would be necessary to pay more attention to the offer of events, which would impact the Luznava Manor's attractiveness. The Manor's current and prospective attractiveness of the service is to organize the events for certain audiences looking for something special, the events, which are not targeted at the mass audience, while providing a special aura, service, exclusivity.

The experts believe that the Luznava Manor has a high aesthetic value; still the other elements characterizing criteria of cultural significance make one to think about a controversial situation. Despite the fact that the Luznava Manor is considered to be the pearl of Art Nouveau, its uniqueness, historical significance, educational, social and scientific value requires a significant further exploration. The authors believe it is necessary to enrich the Luznava Manor's historical information by tpurposefully and continuously supplementing the Manor's funds with new historical informative and photo materials. That would clearly contribute to the historic significance of the Manor, would increase its educational and scientific value.

\section{Conclusion}

1. The authors believe that the Luznava Manor as a tourism product must continue to comply with the sustainable tourism principles and criteria. That means, while developing the tourism product, the local cultural, natural, social, and economic factors have to be taken into account. The existing landscape park and pond system of the Luznava Manor are 
important assets to foster educational and active tourism. Provided that the Luznava Manor is located in the territory of the Rāzna National Park, a complementary tourism product offer for active tourism enthusiasts could be developed.

2. The assortment of tourism products is very wide. This means that, like in any other sector, innovations shall be introduced. Throughout the world, in the tourism industry - including museums - information technologies are actively used. The authors believe that the Luznava Manor's tourism offer should be designed in accordance with the basic principles of an innovative tourism product (quests or information presented by a variety of digital, such as $4 \mathrm{D}$ or $5 \mathrm{D}$, simulations are offered to visitors). It is important that the offer constantly changes in order to encourage visitors to return again.

3. Currently, it is relatively difficult to evaluate the Luznava Manor's tourism product as a global or European level tourist destination. According to the authors, the Luznava Manor is rather to be considered as a tourist destination of national, regional and local significance. That means the tourism product offer has to be developed accordingly. In order to consider the Luznava Manor as a global or at least European destination/object, an excellent recognition is required and elaboration of a special product, that is non-existent anywhere else.

4. It is necessary to pay a special attention to the Luznava Manor's tourism product quality. In order to promote the demand for the Luznava manor as a tourism product, it is necessary to meet more than local tourists' needs and to eliminate all possible barriers of access to information and language barriers.

5. It is necessary to provide a high added value to the Luznava manor as a tourist product. This can be achieved by improving the staff's professionalism and knowledge about the Luznava Manor and its history. Foreign language skills, employees' appearance, professionalism are essential for successful development of the Luznava Manor.

6. It is necessary to ensure a high level of engagement of tourists and allow them to gain new experiences. Interactive and exploratory tours could be provided, educational expositions designed in the Luznava Manor.

7. In the Luznava Manor Park, exploring trails could be developed that would be demanded by local students' excursions. Moreover, interesting and thematic recreational zones could be designed in the park, which could be rented at a reasonable price, for example, for children's events, birthday parties and so on. In this case, the target audience is the local population, which means that the price of the service has to be moderate in order to stimulate the interest to use the service. 
8. The spacious Luznava Manor Park is the ideal place for active tourism enthusiasts. This means that, for the exploration of the park, different modes of transport could be used.

9. The Luznava Manor is attractive and significant place for local tourists, but it is necessary to pay attention and make this tourism destination more attractive with different tools (example, the soup serving tradition - to present a soup using a narration in a genuine language of that time; involve volunteer guides (people who are experts in a specific area and who willingly want to and can share the information on the subject) etc.).

\section{References}

Cracolici, M.F., Nijkamp, P. (2009). The Attractiveness and Competitiveness of Tourist Destinations: A study of Southern Italian regions. Tourism Management, 336-344.

Region Policy (2014). European Commission website. Retrieved: http://ec.europa.eu/regional policy/lv/policy/ themes/tourism/ (Accessed on 03.11.2016.)

Formica, S. (2000). Destination Attractiveness as a Function of Supply and Demand Interaction. - PhD. Dissertation, Virginia Polytechnic Institute and State University

Gunn, C. (1979). Tourism Planning. Crane Russak, New York. 269-279.

$\mathrm{Hu}$, Y., Ritchie,B. J. R. (1993). Measuring Destination Attractiveness: A Contextual Approach. Journal of Travel Research. Vol. 32, No. 2, 25-34.

Kim, S.S., Agrusa, J. (2005). The Positioning of Overseas Honeymoon Destinations. Annals of Tourism Research, 887-904.

Krešić, D. (2007). Faktori Atraktivnosti Turističkih Destinacija u Funkciji Konkurentnosti. Acta Turistica, 19(1), 45-82.

Kušen, E. (2002). Turistička Atrakcijska Osnova. Zagreb: Institut za turizam.

Leask, A. (2010). Progress in Visitor Attraction Research: Towards More Effective Management. Tourism Management, 155-166.

Lew, A.A. (1987). A Framework of Tourist Attraction Research. Annals of Tourism Research, 14(4), 553-575.

Lue, C-C., Crompton, J.L.\& Stewart, W.P. (1996). Evidence of Cumulative Attraction in Multidestination Recreational Trip Decisions. Journal of Travel Research, 35(1), 41-49.

Mayo, E. J., Jarvis, L. P. (1981). The Psychology of Leisure Travel. Effective Marketing and Selling of Travel Services. Boston, MA: CBI Publishing Company.

Meinung, A. (1989). Determinants of the Attractiveness of Tourism Region. In: Witt, S. F. \& Moutinho, L. (Eds.) Tourism Marketing and Management Handbook (pp. 99·101), London: Prentice $\cdot$ Hilll.

Mihalič, T. (2000). Environmental Management of a Tourist Destination: A Factor of Tourism Competitiveness. Tourism Management, 21(1), 65-78.

Morachat, C. (2003). A Study Of Destination Attractiveness Through Tourists' Perspectives: A Focus On Chiang Mai, Thailand. Retrieved from http://ro.ecu.edu.au/theses/1504

Omerzel Gomzelj, D., Mihalič, T. (2008). Destination competitiveness-Applying Different Models, the Case of Slovenia. Tourism Management, 294-307.

Pikkemaat, B. (2004). The Measurement of Destination Image:The Case of Austria. The Poznan University of Economics Review, 87-102. 
Pompurová, K. (2010). Komplexné zhodnotenie atraktívnosti Česka ako ciel’ovej krajiny cestovného ruchu pre európsky frankofónny trh. Czech hospitality and tourism papers: hotelnictví, lázeňství, turismus, 12

Ritchie, B.J., Crouch, G.I. (2005). The Competitive Destination: A Sustainable Tourism Perspective. Wallingford: CABI Publishing.

Schejbal, C. (2013). Evaluation of Tourist Destination Attractiveness. Acta Logistica, 2, 2 , $18-27$.

Um, S., Chon, K. \& Ro, Y. (2006). Antecedents of revisit intention. Annals of Tourism Research, 1141- 1158.

Vengesayi, S. (2003). Destination Attractiveness and Destination Competitiveness: A Model of Destination Evaluation. ANZMAC 2003 Conference Proceedings Adelaide 1-3 December 2003, Monash University, 637 - 645.

Yoon, Y., Uysal, M. (2005). An Examination of the Effects of Motivation and Satisfaction on Destination Loyalty: a Structural Model. Tourism Management, 45-56. 